\title{
Effect of Lime Particle Size on Melting Behavior of Lime-containing Flux
}

\author{
Jian YANG, Mamoru KUWABARA, Takashi ASANO, Akihiro CHUMA and Jun DU \\ Department of Materials, Physics and Energy Engineering, Graduate School of Engineering, Nagoya University, Furo-cho, \\ Chikusa-ku, Nagoya, Aichi 464-8603 Japan.
}

(Received on May 17, 2007; accepted on August 16, 2007)

\begin{abstract}
By use of an infrared-ray vacuum furnace, effect of $\mathrm{CaO}$ particle size on melting behavior of lime-containing flux is studied in the present work. Two kinds of $\mathrm{CaO}$ particles of the average diameters of $10 \mu \mathrm{m}$ and $75 \mu \mathrm{m}$ are used. Four kinds of lime-containing fluxes are employed, which are $\mathrm{CaO}-\mathrm{SiO}_{2}, \mathrm{CaO}-\mathrm{FeO}$, $\mathrm{CaO}-\mathrm{SiO}_{2}-\mathrm{Al}_{2} \mathrm{O}_{3}$ as ironmaking slag and $\mathrm{CaO}-\mathrm{SiO}_{2}-\mathrm{FeO}$ as steelmaking slag.

The relationships of reaction products, heating temperature and holding time are obtained for the fluxes of $\mathrm{CaO}-\mathrm{SiO}_{2}$ and $\mathrm{CaO}-\mathrm{FeO}$ under the present experimental conditions. As for the flux melting, decreasing the lime particle size can shorten the holding time, but can not decrease the heating temperature. In the melting process of $\mathrm{CaO}-\mathrm{SiO}_{2}$, a layer of $2 \mathrm{CaO} \cdot \mathrm{SiO}_{2}$ is observed on the periphery of $\mathrm{CaO}$ particle, which tends to inhibit the melting of $\mathrm{CaO}$ particles. Decreasing the $\mathrm{CaO}$ particle size can also effectively promote the dissolution of $\mathrm{CaO}$ particles into both kinds of slag of $\mathrm{CaO}-\mathrm{SiO}_{2}-\mathrm{Al}_{2} \mathrm{O}_{3}$ and $\mathrm{CaO}-\mathrm{SiO}_{2}-\mathrm{FeO}$.
\end{abstract}

KEY WORDS: lime-containing flux; melting; dissolution of lime; slag formation; particle size of lime.

\section{Introduction}

Lime-containing flux is widely used as a reagent of desulfurization and dephosphorization in ironmaking and steelmaking process. However, since the melting point of $\mathrm{CaO}$ is as high as $2843 \mathrm{~K},{ }^{1)}$ which is much higher than the ordinary temperature for ironmaking and steelmaking, lowering the melting point of flux is usually done by addition of gangue minerals of $\mathrm{SiO}_{2}$ and $\mathrm{Al}_{2} \mathrm{O}_{3}$ to enhance the reaction rate between slag and molten metal. For further promoting the melting of lime-containing flux, fluorspar $\left(\mathrm{CaF}_{2}\right)$ is also commonly used as an additive. But owing to fluorine containing species released into atmosphere and dissolved into soil from the disposed slag, utilization of fluorspar is increasingly limited from the view point of environmental protection.

Many methods have been developed to promote the melting of lime-containing flux in place of using fluorspar $\left(\mathrm{CaF}_{2}\right)$. Shoji et al. $^{2)}$ indicated that desulfurization could be improved by addition of aluminum into hot metal in the powdered lime injection process. Instead of $2 \mathrm{CaO} \cdot \mathrm{SiO}_{2}$ and $3 \mathrm{CaO} \cdot \mathrm{SiO}_{2}$ layer formed on the lime surface, which retarded sulfur transferring to its interior, the molten $\mathrm{CaO}-$ $\mathrm{Al}_{2} \mathrm{O}_{3}-\mathrm{FeO}$ layer was formed on the lime surface to enhance sulfur transfer. Ban-ya et al. ${ }^{3)}$ developed $\mathrm{CaO}-\mathrm{Al}_{2} \mathrm{O}_{3}-$ $\mathrm{Fe}_{x} \mathrm{O}_{y}$ flux as a substitute for $\mathrm{CaO}-\mathrm{CaF}_{2}-\mathrm{Fe}_{x} \mathrm{O}_{y}$ flux, which was commonly used for dephosphorization and desulfurization of hot metal. The most suitable composition for dephosphorization was $(38-45) \mathrm{CaO}-(12-5) \mathrm{Al}_{2} \mathrm{O}_{3}-50 \mathrm{Fe}_{x} \mathrm{O}_{y}$ in weight percentage. Mukawa et al. obtained the optimum $\mathrm{Na}_{2} \mathrm{O}$ content in $\mathrm{Na}_{2} \mathrm{O}-\mathrm{CaO}$ flux, ${ }^{4)}$ and the optimum $\mathrm{Al}_{2} \mathrm{O}_{3}$ content in $\mathrm{CaO}-\mathrm{Al}_{2} \mathrm{O}_{3}$ flux ${ }^{5)}$ to gain the maximum rate of desulfurization of hot metal. Shimoda et al. ${ }^{6)}$ proposed that $\mathrm{CaO}-\mathrm{Al}_{2} \mathrm{O}_{3}-\mathrm{TiO}_{2}$ flux had the greatly promoting effect on desulfurization of hot metal, due to its low melting point and low viscosity. Furthermore, Lee et $a l^{7)}$ developed a new flux of burnt lime $(\mathrm{CaO})$ coated with di-calcium ferrite $(2 \mathrm{CaO} \cdot \mathrm{FeO})$. It was claimed that this new kind of flux had a high resistance to hydration and a capacity of fast and complete dissolution into the steelmaking slag of BOF and EAF.

On the other hand, much research work has been tried to clarify the mechanism of dissolution of lime into slag and develop the new methods to promote the dissolution. Schlitt et $\mathrm{al}{ }^{8)}$ found that the dissolution rate of lime into $\mathrm{CaO}-$ $\mathrm{FeO}-\mathrm{SiO}_{2}$ slag was markedly increased with increasing the $\mathrm{FeO}$ content in slag. It was also revealed ${ }^{9)}$ that the layer of $2 \mathrm{CaO} \cdot \mathrm{SiO}_{2}$ was formed on the surface of $\mathrm{CaO}$ particles, and dissolution of $\mathrm{CaO}$ proceeded by migration of the molten slag through cracks on the layer of $2 \mathrm{CaO} \cdot \mathrm{SiO}_{2}$. In the case of the higher $\mathrm{Fe}_{2} \mathrm{O}_{3}$ content, the layers of $2 \mathrm{CaO}$. $\mathrm{SiO}_{2}$ and $3 \mathrm{CaO} \cdot \mathrm{SiO}_{2}$ compounds formed around the $\mathrm{CaO}$ crystal were not continuous but looked like particles, which promoted dissolution of $\mathrm{CaO} .{ }^{10)}$ The diffusion of calcium through the slag boundary phase was revealed to be the rate-determining step for dissolution of solid lime into the liquid slag of $\mathrm{CaO}-\mathrm{SiO}_{2}-\mathrm{Al}_{2} \mathrm{O}_{3}$ or $\mathrm{CaO}-\mathrm{SiO}_{2}-\mathrm{FeO}{ }^{11)}$ In addition, more porous lime was found to show higher reactivity in dissolution of lime into slag. ${ }^{12)}$ It was concluded $^{13,14)}$ that the effect of the additives to $\mathrm{Fe}_{\mathrm{t}} \mathrm{O}-\mathrm{CaO}-$ $\mathrm{SiO}_{2}$ melt on increasing the dissolution rate of $\mathrm{CaO}$ was in the order of $\mathrm{CaF}_{2}>\mathrm{CaCl}_{2}>\mathrm{B}_{2} \mathrm{O}_{3}>\mathrm{Al}_{2} \mathrm{O}_{3}$. Addition of $\mathrm{CaF}_{2}$, 


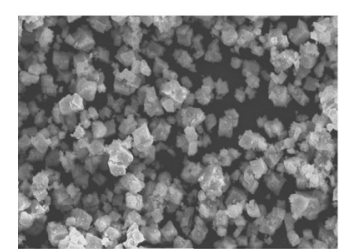

$\mathrm{CaO}(10 \mu \mathrm{m})$

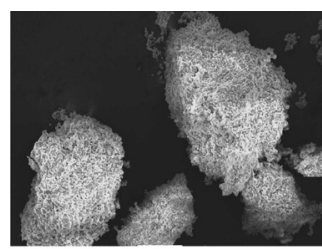

$\mathrm{CaO}(75 \mu \mathrm{m})$

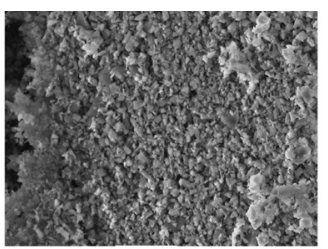

$\mathrm{SiO}_{2}$

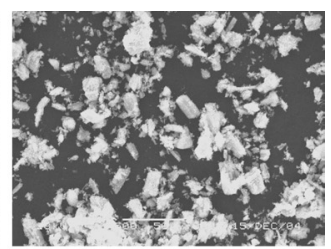

$\mathrm{Fe}_{2} \mathrm{O}_{3}$
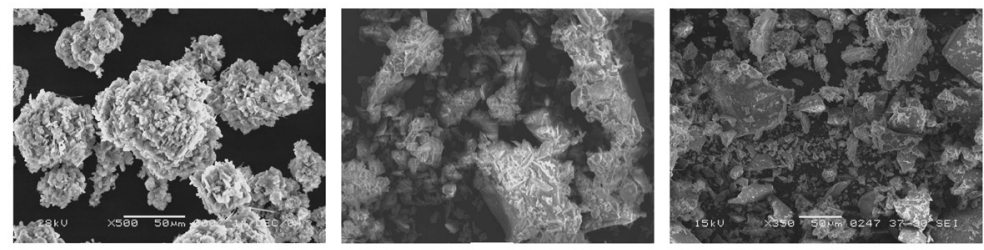

$50 \mu \mathrm{m}$

$\mathrm{Al}_{2} \mathrm{O}_{3}$

$\mathrm{CaO}-\mathrm{SiO}_{2}-\mathrm{Al}_{2} \mathrm{O}_{3}$

$\mathrm{CaO}-\mathrm{SiO}_{2}-\mathrm{FeO}$

Fig. 1. Morphologies of all kinds of materials used in experiments.

$\mathrm{MnO}_{x}, \mathrm{FeO}_{x}$, and $\mathrm{TiO}_{2}$ into $\mathrm{Al}_{2} \mathrm{O}_{3}-\mathrm{CaO}-\mathrm{SiO}_{2}$ slag increased the dissolution rate of lime into slag, while addition of $\mathrm{SiO}_{2}$ had an opposite effect. ${ }^{15)}$

In the present work, by use of infrared-ray vacuum furnace, effect of lime particle size on melting behavior of lime-containing flux is studied. Four kinds of fluxes are employed, which are $\mathrm{CaO}-\mathrm{SiO}_{2}, \mathrm{CaO}-\mathrm{FeO}, \mathrm{CaO}-\mathrm{SiO}_{2}-\mathrm{Al}_{2} \mathrm{O}_{3}$ as ironmaking slag and $\mathrm{CaO}-\mathrm{SiO}_{2}-\mathrm{FeO}$ as steelmaking slag. The used two different sizes of $\mathrm{CaO}$ particles have the average diameters of 10 and $75 \mu \mathrm{m}$. For the different kinds of fluxes, the relationships of reaction products, heating temperature and holding time are obtained from analysis results of XRD patterns. The status of flux melting is observed with a scanning electron microscope (SEM) and is analyzed with an energy dispersive spectrometer (EDS).

\section{Experimental Apparatus and Procedures}

Figure 1 shows the morphologies of all kinds of materials before formation of pellets. Calcium oxide particles of the small size, which were the commercial reagent packed with Ar gas, were relatively uniform in diameter, having the average diameter of $10 \mu \mathrm{m}$ with the purity of $99.9 \%$. Calcium oxide particles of the large size were prepared as rapidly as possible by crushing the calcium oxide blocks of the commercial reagent and being sieved with sieve pores of $50 \mu \mathrm{m}$ and $100 \mu \mathrm{m}$, having the average diameter of $75 \mu \mathrm{m}$ and the purity of $99.9 \%$. Silicon oxide powders were very fine in size with the average diameter of only $2.0 \mu \mathrm{m}$. $\alpha$ hematite powders had greatly varied diameters and irregular shapes, having the average diameter of $15 \mu \mathrm{m}$ and purity of $99.5 \%$. The diameters of aluminium oxide powders were varied, ranging from 20 to $80 \mu \mathrm{m}$. The aluminum oxide particles were usually in clusters formed by many fine aluminum oxide powders and the aluminum oxide powders had the purity of $99.9 \%$.

Slag 1 of $\mathrm{CaO}-\mathrm{SiO}_{2}-\mathrm{Al}_{2} \mathrm{O}_{3}$ was produced by melting the mixture of $\mathrm{CaO}, \mathrm{SiO}_{2}$ and $\mathrm{Al}_{2} \mathrm{O}_{3}$ powders at the mass ratio of $40: 40: 20(\operatorname{mass} \%)$, which is closed to the common composition of slag used in blast furnace, in a dense $\mathrm{Al}_{2} \mathrm{O}_{3}$ crucible using an electric resistance furnace. Slag 2 of $\mathrm{CaO}-\mathrm{SiO}_{2}-\mathrm{FeO}$ was made by melting the mixture of $\mathrm{CaO}$, $\mathrm{SiO}_{2}, \mathrm{FeO}$ powders at the mass ratio of $40: 40: 20$ (mass $\%$ ),
Table 1. Chemical compositions and powder sizes of experimental samples together with used crucibles.

\begin{tabular}{|c|c|c|c|c|}
\hline \multirow{2}{*}{ Sample 1 } & \multicolumn{2}{|c|}{$\begin{array}{c}\text { Chemical composition } \\
\text { (mass\%) }\end{array}$} & $\begin{array}{c}\text { Average Powder } \\
\text { size }(\mu \mathrm{m})\end{array}$ & Crucible \\
\cline { 2 - 4 } & $\mathrm{CaO}$ & 37.0 & 10 or 75 & \multirow{2}{*}{$\mathrm{C}$} \\
\hline \multirow{2}{*}{ Sample 2 } & $\mathrm{SiO}_{2}$ & 63.0 & 2 & \multirow{2}{*}{$\mathrm{Al}_{2} \mathrm{O}_{3}$} \\
\cline { 2 - 4 } & $\mathrm{CaO}$ & 20.0 & 10 or 75 & \multirow{2}{*}{$\mathrm{C}$} \\
\hline \multirow{2}{*}{ Sample 3 } & $\mathrm{Fe}_{2} \mathrm{O}_{3}$ & 80.0 & 15 & \multirow{2}{*}{$\mathrm{Al}_{2} \mathrm{O}_{3}$} \\
\cline { 2 - 4 } & $\mathrm{CaO}^{2}$ & 10.0 & 10 or 75 & \multirow{2}{*}{30} \\
\hline
\end{tabular}

Slag compositions:

Slag 1: $\mathrm{CaO}: \mathrm{SiO}_{2}: \mathrm{Al}_{2} \mathrm{O}_{3}=40: 40: 20$ (mass\%)(used in ironmaking)

Slag 2: $\mathrm{CaO}: \mathrm{SiO}_{2}: \mathrm{FeO}=40: 40: 20$ (mass\%)(used in steelmaking)

which is near the common composition of slag used in steelmaking, also in a dense $\mathrm{Al}_{2} \mathrm{O}_{3}$ crucible using an electric resistance furnace. And then both kinds of slag were crushed in a mortar, having greatly varied diameters from 5 to $200 \mu \mathrm{m}$ with the average diameter of about $30 \mu \mathrm{m}$.

The components of samples are shown in Table 1. Sample 1 contained $\mathrm{CaO}$ and $\mathrm{SiO}_{2}$ of a mass ratio of $37: 63$ (mass\%), which was the eutectic composition having the melting point of $1709 \mathrm{~K}$. ${ }^{1)}$ Sample 2 consisted of $\mathrm{CaO}$ and $\mathrm{Fe}_{2} \mathrm{O}_{3}$ of a mass ratio of 20:80 (mass\%), which was near the eutectic composition having the meting point of $1473 \mathrm{~K}^{16)}$ In Sample 3, Slag 1 of $\mathrm{CaO}-\mathrm{SiO}_{2}-\mathrm{Al}_{2} \mathrm{O}_{3}$ and $\mathrm{CaO}$ were mixed at a mass ratio of 90:10 (mass\%). In Sample 4, Slag 2 of $\mathrm{CaO}-\mathrm{SiO}_{2}-\mathrm{FeO}$ and $\mathrm{CaO}$ were mixed at a mass ratio of 90:10 (mass\%). After mixing, the above four kinds of samples were respectively formed into pellets, having the diameter of $3 \mathrm{~mm}$ and the length of $2 \mathrm{~mm}$, by use of a cold isostatic press (CIP) under a pressure of $150 \mathrm{MPa}$ for $1 \mathrm{~h}$.

Figure 2 is a schematic diagram of the infrared vacuum furnace. On the each side of the furnace, a infrared lamp was placed at the first focal spot of a golden ellipsoidal reflecting mirror, while the heating sample was located at the 


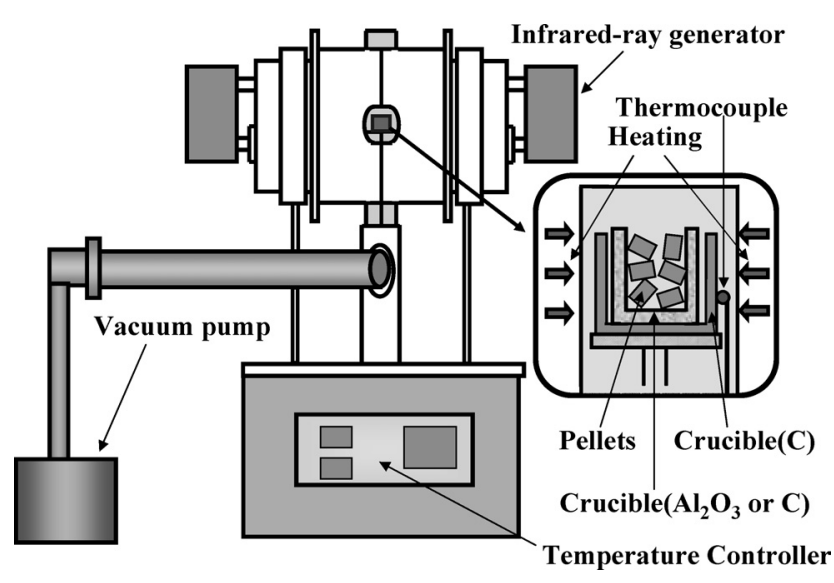

Fig. 2. Schematic illustration of infrared ray vacuum furnace.

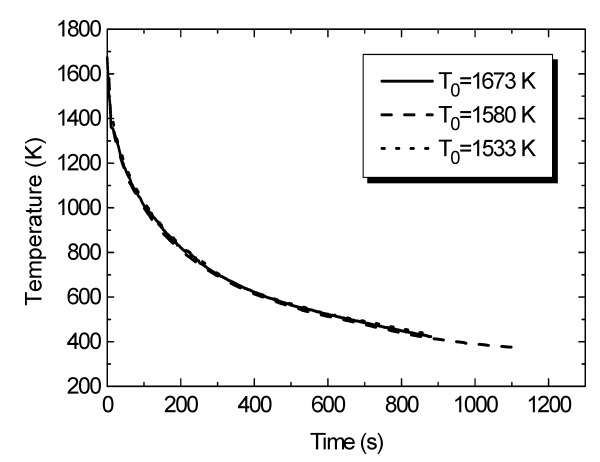

Fig. 3. Decrease in temperature with time after cutting down the electric power supply of the furnace.

second focal spot. In this way, the sample could be heated up to a high temperature in a short time mainly by heat radiation mechanism. The pellets of the mass of $0.34 \pm 0.01 \mathrm{~g}$ were placed in an alumina or graphite sample crucible. Since the pellet mass was rather small, the heat transfer in the pellets should not be the rate-controlling step. Furthermore, in order to ensure the pellets to be uniformly heated, the sample crucible was placed inside a larger graphite crucible that had good conductivity. The temperature was measured by a thermocouple with its front edge attached to the side wall of the protection graphite crucible. From the above heating principle, the temperature measured by the thermocouple should be close to the temperature in the pellets. But the specific difference needs to be studied in the future. The pellets, crucibles and thermocouple were sealed in a transparent quartz tube, in which $1 \times 10^{-7}$ atm of vacuum degree could be retained by a vacuum pump. Infrared ray was focused to heat the pellet from two infrared ray generators located on the two lateral sides. Increasing and decreasing in temperature were adjusted by temperature controlling program.

The pellets were heated at the temperature increasing rate of $300 \mathrm{~K} / \mathrm{min}$. After holding for a certain time at the prescribed temperature, they were cooled to the room temperature as quickly as possible by shutting down the electric power supply. The decrease in temperature with time after turning off the electric power supply of the furnace is shown in Fig. 3. For all of the initial temperatures of 1673 , 1580 and $1533 \mathrm{~K}$, it took about only $70 \mathrm{~s}$ to decrease to $1100 \mathrm{~K}$, having the initial temperature decreasing rate of larger than $370 \mathrm{~K} / \mathrm{min}$. And below $1100 \mathrm{~K}$, all of the sam-

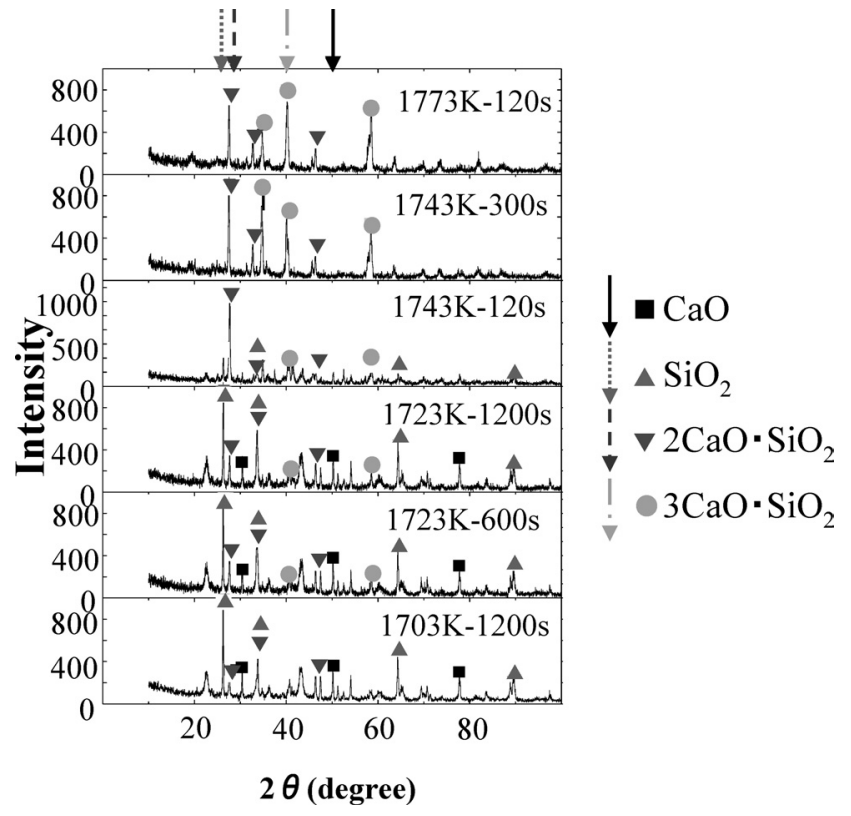

Fig. 4. $\mathrm{XRD}$ patterns of $\mathrm{CaO}-\mathrm{SiO}_{2}$ pellet after heating at different temperatures for various times. $(\mathrm{CaO}$ average diameter of $75 \mu \mathrm{m}$ )

ples used in the present experiments have not any new phase transformation. It is therefore deduced that the phases of samples after cooling to the room temperature are close to the phases held at the experimental temperatures. Then the components of the reaction products after heating were determined by use of X-ray diffraction (XRD). Crosssection of the cooled pellets were observed using SEM. The microscopic compositions at various positions on the pellet surface were determined by EDS analysis.

\section{Experimental Results and Discussion}

\subsection{Melting of $\mathrm{CaO}-\mathrm{SiO}_{2}$ Flux}

From the $\mathrm{CaO}-\mathrm{SiO}_{2}$ binary phase diagram, Sample 1 of $\mathrm{CaO}-\mathrm{SiO}_{2}$ at the mass ratio of $37: 63$ (mass\%) has the eutectic composition of the melting point of $1709 \mathrm{~K}$. Therefore, for $\mathrm{CaO}$ of the average particle diameter of $75 \mu \mathrm{m}$, samples were heated at $1703 \mathrm{~K}$ for $1200 \mathrm{~s}$, at $1723 \mathrm{~K}$ for $600 \mathrm{~s}$ and $1200 \mathrm{~s}$, at $1743 \mathrm{~K}$ for $120 \mathrm{~s}$ and $300 \mathrm{~s}$, at $1773 \mathrm{~K}$ for $120 \mathrm{~s}$, respectively. The cooled samples were analyzed with XRD and the results are shown in Fig. 4.

It is seen that after heating at the temperature of $1703 \mathrm{~K}$ below the melting point, the pellets mainly contained $\mathrm{CaO}$ and $\mathrm{SiO}_{2}$. Some $2 \mathrm{CaO} \cdot \mathrm{SiO}_{2}$ was also formed during the heating. With increasing the heating temperature and holding time, the intensities of $\mathrm{CaO}$ peak and $\mathrm{SiO}_{2}$ peak decreased. The peaks of $\mathrm{CaO}$ disappeared at $1743 \mathrm{~K}$ for $120 \mathrm{~s}$, and the peaks of $\mathrm{SiO}_{2}$ disappeared at $1743 \mathrm{~K}$ for $300 \mathrm{~s}$.

From above XRD results, the relationships of reaction products, heating temperature and holding time can be summarized as in Fig. 5. It clearly shows that in the reaction products after heating, $\mathrm{CaO}$ and $\mathrm{SiO}_{2}$ disappeared in turn, while $2 \mathrm{CaO} \cdot \mathrm{SiO}_{2}$ and $3 \mathrm{CaO} \cdot \mathrm{SiO}_{2}$ appeared in turn with increasing the heating temperature and holding time. The solid line in the figure represents the boundary line of pellet meltdown determined by SEM observation of pellets 
after heating, which will be explained later.

For $\mathrm{CaO}$ of the average diameter of $10 \mu \mathrm{m}$, samples 1 were heated at $1703 \mathrm{~K}$ for $1200 \mathrm{~s}$, at $1723 \mathrm{~K}$ for $600 \mathrm{~s}$, at $1723 \mathrm{~K}$ for $1200 \mathrm{~s}$ and at $1743 \mathrm{~K}$ for $120 \mathrm{~s}$. The similar changes in the compositions of pellets after heating were found as shown in Fig. 6. But the peaks of $\mathrm{SiO}_{2}$ disappeared at $1743 \mathrm{~K}$ for $120 \mathrm{~s}$. The holding time is shorter than $300 \mathrm{~s}$ for $\mathrm{CaO}$ of the average diameter of $75 \mu \mathrm{m}$. In addition, the peaks of $3 \mathrm{CaO} \cdot \mathrm{SiO}_{2}$ appeared from $1703 \mathrm{~K}$ holding for $1200 \mathrm{~s}$, the heating temperature was lower than $1723 \mathrm{~K}$ for $\mathrm{CaO}$ of the average diameter of $75 \mu \mathrm{m}$. These results can be clearly summarized in Fig. 7, which shows the relationships of reaction products, heating temperature and holding time for $\mathrm{CaO}$ of the average diameter of $10 \mu \mathrm{m}$.

Figure 8 gives results of SEM images and EDS analyses for $\mathrm{CaO}(75 \mu \mathrm{m})-\mathrm{SiO}_{2}$ pellet after heating at $1703 \mathrm{~K}$ for $1200 \mathrm{~s}$, at $1743 \mathrm{~K}$ for $120 \mathrm{~s}$ and $300 \mathrm{~s}$. After heating at $1703 \mathrm{~K}$ for $1200 \mathrm{~s}$, the individual $\mathrm{CaO}$ particle still remained in the pellet as shown in diagram (a). EDS analysis shows that $\mathrm{CaO}$ was mainly contained at the center of the particle. A product layer was observed around the periphery

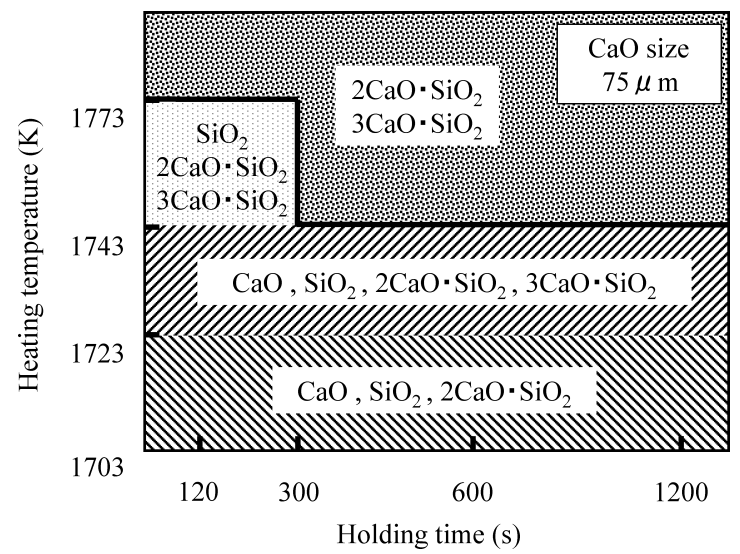

Fig. 5. Relationships of reaction products, heating temperature and holding time after heating $\mathrm{CaO}-\mathrm{SiO}_{2}$ pellet at different temperatures for various times. ( $\mathrm{CaO}$ average diameter of $75 \mu \mathrm{m}$ ) of the $\mathrm{CaO}$ particle from the SEM image. EDS analysis indicates that it had the component close to $2 \mathrm{CaO} \cdot \mathrm{SiO}_{2}$, which theoretically contains $\mathrm{CaO}$ of 65.1 mass $\%$. It is obvious that the pellet was not melting at this temperature. The $2 \mathrm{CaO} \cdot \mathrm{SiO}_{2}$ layer retarded the mutual mass transfer of the

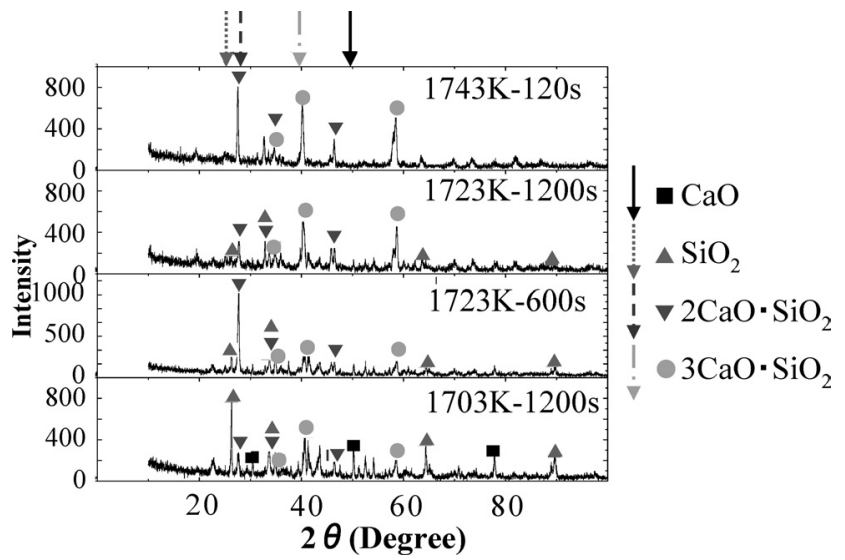

Fig. 6. XRD patterns of $\mathrm{CaO}-\mathrm{SiO}_{2}$ pellet after heating at different temperatures for various times. ( $\mathrm{CaO}$ average diameter of $10 \mu \mathrm{m})$

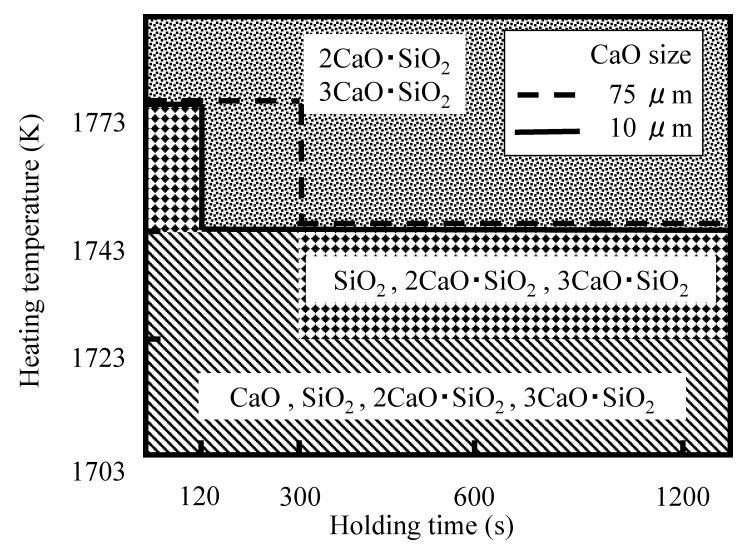

Fig. 7. Relationships of reaction products, heating temperature and holding time after heating $\mathrm{CaO}-\mathrm{SiO}_{2}$ pellet at different temperatures for various times. ( $\mathrm{CaO}$ average diameter of $10 \mu \mathrm{m})$

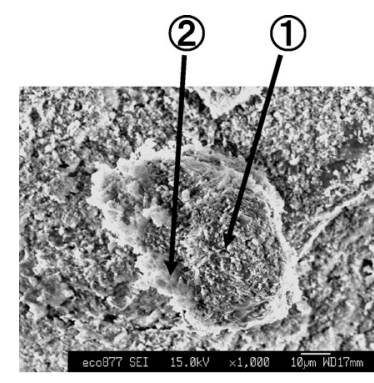

(a) $1703 \mathrm{~K}$ holding for $1200 \mathrm{~s}$

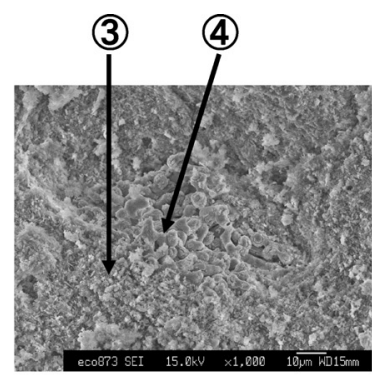

(b) $1743 \mathrm{~K}$ holding for $120 \mathrm{~s}$

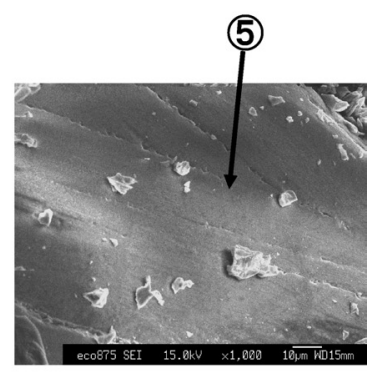

(c) $1743 \mathrm{~K}$ holding for $300 \mathrm{~s}$

EDS analysis results (mass\%)

\begin{tabular}{|c|c|c|c|c|c|}
\hline & $(1$ & $(2)$ & $(3)$ & 4 & (5) \\
\hline $\mathrm{CaO}$ & 96.5 & 63.0 & 8.8 & 80.1 & 40.6 \\
\hline $\mathrm{SiO}_{2}$ & 3.5 & 37.0 & 91.2 & 19.9 & 59.4 \\
\hline
\end{tabular}

Fig. 8. SEM images and $\mathrm{EDS}$ analyses of $\mathrm{CaO}(75 \mu \mathrm{m})-\mathrm{SiO}_{2}$ pellet after heating. 


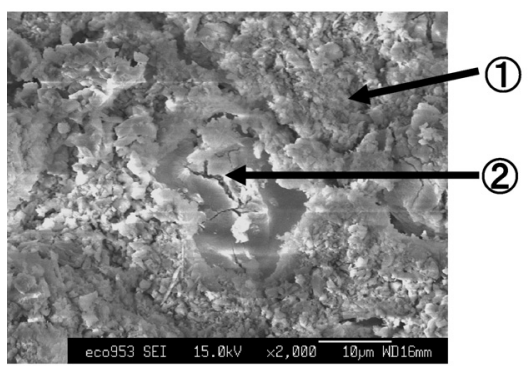

(a) $1703 \mathrm{~K}$ holding for $1200 \mathrm{~s}$

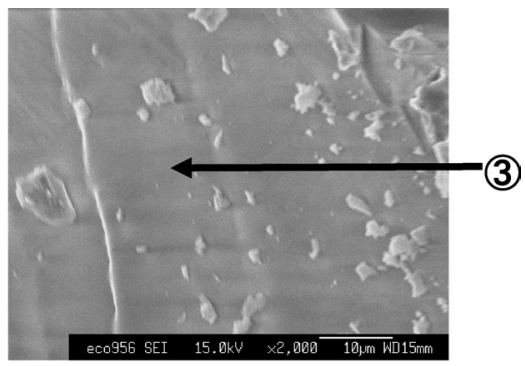

(b) $1743 \mathrm{~K}$ holding for $120 \mathrm{~s}$

EDS analysis results (mass\%)

\begin{tabular}{|c|c|c|}
\hline & $\mathrm{CaO}$ & $\mathrm{SiO}_{2}$ \\
\hline$(1)$ & 1.46 & 98.54 \\
\hline$(2)$ & 75.05 & 24.95 \\
\hline$(3$ & 38.05 & 61.95 \\
\hline
\end{tabular}

Fig. 9. SEM images and EDS analyses of $\mathrm{CaO}(10 \mu \mathrm{m})-\mathrm{SiO}_{2}$ pellet after heating.

$\mathrm{CaO}$ and $\mathrm{SiO}_{2}$ phases.

After heating at $1743 \mathrm{~K}$ for $120 \mathrm{~s}$, the pellet displayed different microstructures at different regions on the pellet surface. The region with the smaller particles at the point (3) in diagram (b) contained mainly $\mathrm{SiO}_{2}$, while the region with the larger particles at the point (4) contained mainly $\mathrm{CaO}$. The pellet was obviously not fully melting. After heating at $1743 \mathrm{~K}$ for $300 \mathrm{~s}$, the uniform appearance on the pellet surface was observed, and the EDS analysis results indicate that its component is the same as the initially mixing ratio of $\mathrm{CaO}$ and $\mathrm{SiO}_{2}$ in the pellets. Therefore, it is confirmed that the pellet was melted down at $1743 \mathrm{~K}$ for $300 \mathrm{~s}$. The boundary line of pellet meltdown is shown as the solid line in Fig. 5.

Figure 9 shows the results of SEM images and EDS analyses of $\mathrm{CaO}(10 \mu \mathrm{m})-\mathrm{SiO}_{2}$ pellet after heating at $1703 \mathrm{~K}$ for $1200 \mathrm{~s}$ and at $1743 \mathrm{~K}$ for $120 \mathrm{~s}$. At $1703 \mathrm{~K}$ holding for $1200 \mathrm{~s}$, different morphologies appeared at different regions on the pellet surface. At the point (1), the dominant component was $\mathrm{SiO}_{2}$. On the other hand, at the point (2), the primary component was $\mathrm{CaO}$. Thus the pellet was not fully melting under this condition. At $1743 \mathrm{~K}$ holding for $120 \mathrm{~s}$, uniform appearance on the pellet surface indicates that the pellet was meltdown. The EDS analysis result shows that it had the same components as the initially mixing ratio of $\mathrm{CaO}$ and $\mathrm{SiO}_{2}$. Therefore, the meltdown of pellet was confirmed.

In Fig. 7, the solid line is the meltdown boundary line for $\mathrm{CaO}$ of the average particle size of $10 \mu \mathrm{m}$, while the dashed line gives the meltdown boundary line for $\mathrm{CaO}$ of the average particle size of $75 \mu \mathrm{m}$. From Figs. 5 and 7, it is known that only $2 \mathrm{CaO} \cdot \mathrm{SiO}_{2}$ and $3 \mathrm{CaO} \cdot \mathrm{SiO}_{2}$ remained in the pellet after its melting. When the average diameter of $\mathrm{CaO}$ particles was decreased from 75 to $10 \mu \mathrm{m}$, the meltdown temperature did not change, but the holding time was shortened from 300 to $120 \mathrm{~s}$. As a result, the melting of CaO$\mathrm{SiO}_{2}$ flux can be promoted by decreasing $\mathrm{CaO}$ particle size. This is because the interface area between $\mathrm{CaO}$ and $\mathrm{SiO}_{2}$ particles is increased by decreasing $\mathrm{CaO}$ particle size.
By observing the lime-containing flux heated on Pt-filament directly through a microscope, Kimura et al. ${ }^{9)}$ found the layer of $2 \mathrm{CaO} \cdot \mathrm{SiO}_{2}$ is formed on the surface of $\mathrm{CaO}$ particles, which hindered dissolution of $\mathrm{CaO}$ into slag. In the present studies, formation of the layer of $2 \mathrm{CaO} \cdot \mathrm{SiO}_{2}$ around the $\mathrm{CaO}$ particles was also observed and $2 \mathrm{CaO}$. $\mathrm{SiO}_{2}$ has a rather high decomposition temperature of $2403 \mathrm{~K}^{1)}$ As the melting point of $\mathrm{CaO}-\mathrm{SiO}_{2}$ flux at the present mass ratio is $1709 \mathrm{~K}$, the reason why the meltdown of pellet did not take place until $1743 \mathrm{~K}$ even if the average diameter of $\mathrm{CaO}$ particle was decreased to $10 \mu \mathrm{m}$ can be attributed to the formation of $2 \mathrm{CaO} \cdot \mathrm{SiO}_{2}$ layer on the surface of $\mathrm{CaO}$ particles.

\subsection{Melting of $\mathrm{CaO}-\mathrm{Fe}_{2} \mathrm{O}_{3}$ Flux}

In our preliminary experiment, it is confirmed that after Sample 2 of $\mathrm{CaO}$ and $\mathrm{Fe}_{2} \mathrm{O}_{3}$ of the mass ratio of $20: 80$ (mass\%) was heated at above $1373 \mathrm{~K}$, the remaining product was $\mathrm{FeO}$ rather than $\mathrm{Fe}_{2} \mathrm{O}_{3}$ at the present vacuum degree of $1 \times 10^{-7} \mathrm{~atm}$. However, thermodynamic calculation indicates that $\mathrm{Fe}_{2} \mathrm{O}_{3}$ should be stable phase at this vacuum degree. The possible reason for the present experimental result is that the oxygen partial pressure was greatly decreased because the oxygen in the atmosphere reacted with the graphite crucible at the elevated temperature in vacuum. The mass ratio of $\mathrm{CaO}$ to $\mathrm{FeO}$ can be converted to be 21.7:78.3 (mass\%) from the composition of Sample 2. From the binary phase diagram of $\mathrm{CaO}$ and $\mathrm{FeO}$, the remaining product after heating Sample 2 at above $1373 \mathrm{~K}$ has the eutectic composition and its melting point is about 1423 K. ${ }^{1)}$ Therefore, Sample 2 was heated at 1373,1423 , 1443 and $1473 \mathrm{~K}$, and was held for 120, 300, 600, $1200 \mathrm{~s}$ at each temperature.

Then the cooled samples were analyzed with XRD and the results are given in Fig. 10. For $\mathrm{CaO}$ particles of the average diameters of $10 \mu \mathrm{m}$ and $75 \mu \mathrm{m}$, no difference in the compositions of the remaining products was detected. After heating at $1373 \mathrm{~K}$ and after heating at $1423 \mathrm{~K}$ for less than $600 \mathrm{~s}$, the remaining products were $\mathrm{CaO}$ and $\mathrm{FeO}$. After 
heating at $1423 \mathrm{~K}$ for more than $600 \mathrm{~s}$, and after heating at 1443 and $1473 \mathrm{~K}$, the remaining products were $\mathrm{CaO}, \mathrm{FeO}$ and $\mathrm{CaO} \cdot 2 \mathrm{FeO}$. With increasing the heating temperature and holding time, $\mathrm{CaO} \cdot 2 \mathrm{FeO}$ was generated.

The cooled samples were further observed and analyzed with SEM-EDS and the results are shown in Fig. 11 for $\mathrm{CaO}$ particles of the average diameter of $75 \mu \mathrm{m}$. After heating at $1443 \mathrm{~K}$ for $300 \mathrm{~s}$, some particles were not melting, and they contained much $\mathrm{CaO}$ as shown for the point (2) in diagram (a). After heating at $1443 \mathrm{~K}$ for $600 \mathrm{~s}$, the uniform appearance was observed on the pellet surface. From EDS analysis, no region contained ultra high $\mathrm{CaO}$ could be detected, thus the sample was melting. But the $\mathrm{CaO}$ content was not uniform at the different points on the pellet surface. This means that the diffusion of $\mathrm{CaO}$ in the melt did not complete. From above observations and analyses, it is verified that sample 2 with the average diameter of $\mathrm{CaO}$ particles of $75 \mu \mathrm{m}$ became melting from heating at $1443 \mathrm{~K}$ for $600 \mathrm{~s}$. The boundary line of pellet meltdown is shown as the dashed line in Fig. 10.

For the average diameter of $\mathrm{CaO}$ particles of $10 \mu \mathrm{m}$, re-

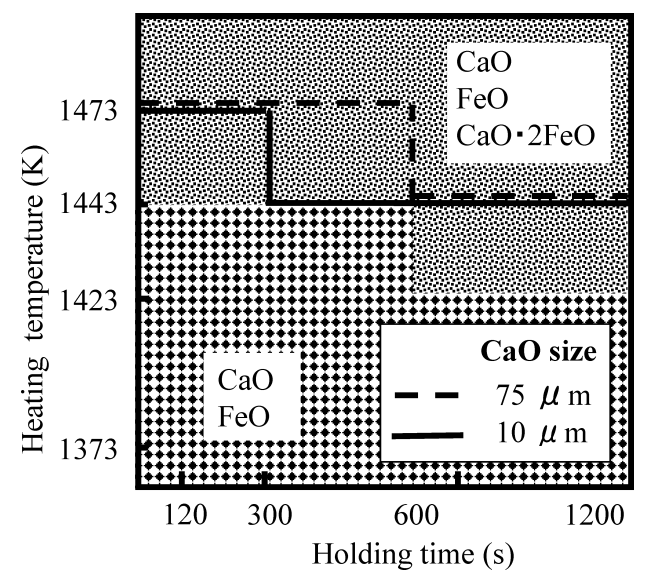

Fig. 10. Relationships of reaction products, heating temperature and holding time after heating $\mathrm{CaO}-\mathrm{FeO}$ flux at different temperatures for various times.

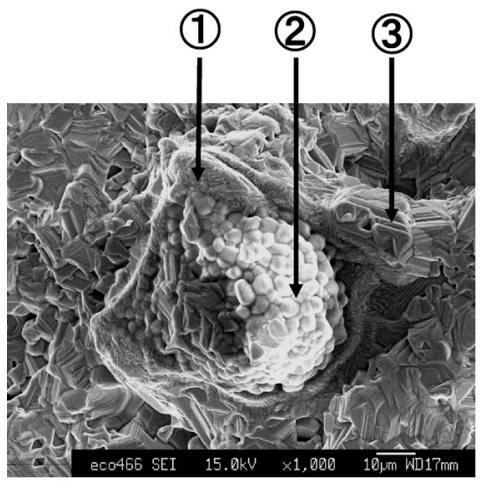

(a) $1443 \mathrm{~K}$ holding for $300 \mathrm{~s}$ sults of SEM images and EDS line analyses are presented in Fig. 12. After heating at $1423 \mathrm{~K}$ for $1200 \mathrm{~s}$, the individual particle made its appearance. EDS line analysis shows that much $\mathrm{CaO}$ was detected across the particle. After heating at $1443 \mathrm{~K}$ for $300 \mathrm{~s}$, the uniform appearance was observed on the pellet surface. EDS line analysis indicates that homogeneous distribution of the $\mathrm{Fe}$ and $\mathrm{Ca}$ contents were detected on the pellet surface. It is confirmed that sample 2 with $\mathrm{CaO}$ particles of the average diameter of $10 \mu \mathrm{m}$ became melting from heating at $1443 \mathrm{~K}$ for $300 \mathrm{~s}$. The boundary line of pellet meltdown for $\mathrm{CaO}$ particles of the average diameter of $10 \mu \mathrm{m}$ is shown as the solid line in Fig. 10. The comparison between the solid and the dashed line clearly shows that with decreasing the $\mathrm{CaO}$ particle size, the melting temperature of $\mathrm{CaO}-\mathrm{FeO}$ flux does not change, but the holding time can be shortened.

\subsection{Melting of $\left(\mathrm{CaO}-\mathrm{SiO}_{2}-\mathrm{Al}_{2} \mathrm{O}_{3}\right)-\mathrm{CaO}$ Flux}

From the ternary phase diagram of $\mathrm{CaO}-\mathrm{SiO}_{2}-\mathrm{Al}_{2} \mathrm{O}_{3}$, Slag 1 containing $\mathrm{CaO}, \mathrm{SiO}_{2}$ and $\mathrm{Al}_{2} \mathrm{O}_{3}$ of the mass percentage ratio of $40: 40: 20$ (mass\%) has the melting point of $1573 \mathrm{~K}$. It is commonly used in the ironmaking process. After 10 mass $\% \mathrm{CaO}$ is mixed with Slag 1, its melting point will rise to $1753 \mathrm{~K}$. Both of Slag 1 and 90 mass $\%$ Slag $1+10$ mass $\% \mathrm{CaO}$ belong to the region of primary crystal of Gehlenite. Therefore, Samples 3 of 90\% Slag 1+10\% $\mathrm{CaO}$ were heated at $1793 \mathrm{~K}$ for $120,300,600$, and $1200 \mathrm{~s}$, respectively.

As Slag 1 in Sample 3 has a much lower melting point than the experimental temperature, Sample 3 was fully melting from its appearance observed with SEM. No difference could be detected for the different holding times at $1793 \mathrm{~K}$.

In terms of the XRD patterns, Slag 1 was preliminarily examined. No elemental substance of $\mathrm{CaO}$ was detected. Therefore, the detected elemental substance of $\mathrm{CaO}$ for Samples 3 after heating was caused by the additionally added $\mathrm{CaO}$ particles. Although the elemental substance of $\mathrm{CaO}$ was detected by XRD patterns for Samples 3, they

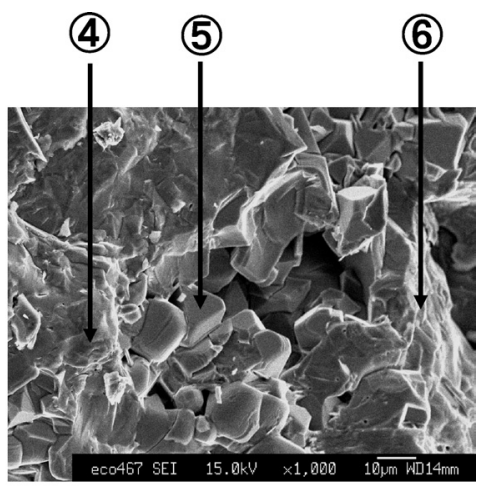

(a) $1443 \mathrm{~K}$ holding for $600 \mathrm{~s}$

\begin{tabular}{|c|c|c|c|c|c|c|}
\hline & $(1)$ & $(2)$ & $(3$ & $(4)$ & $(5)$ & $(6)$ \\
\hline $\mathrm{CaO}$ & 19.4 & 45.9 & 8.7 & 14.4 & 6.8 & 8.8 \\
\hline $\mathrm{Fe}_{2} \mathrm{O}_{3}$ & 80.6 & 54.1 & 91.3 & 85.6 & 93.2 & 91.2 \\
\hline
\end{tabular}

Fig. 11. SEM images and EDS analyses of $\mathrm{CaO}(75 \mu \mathrm{m})-\mathrm{FeO}$ pellet after heating. 
(a) $1423 \mathrm{~K}$ holding for $1200 \mathrm{~s}$
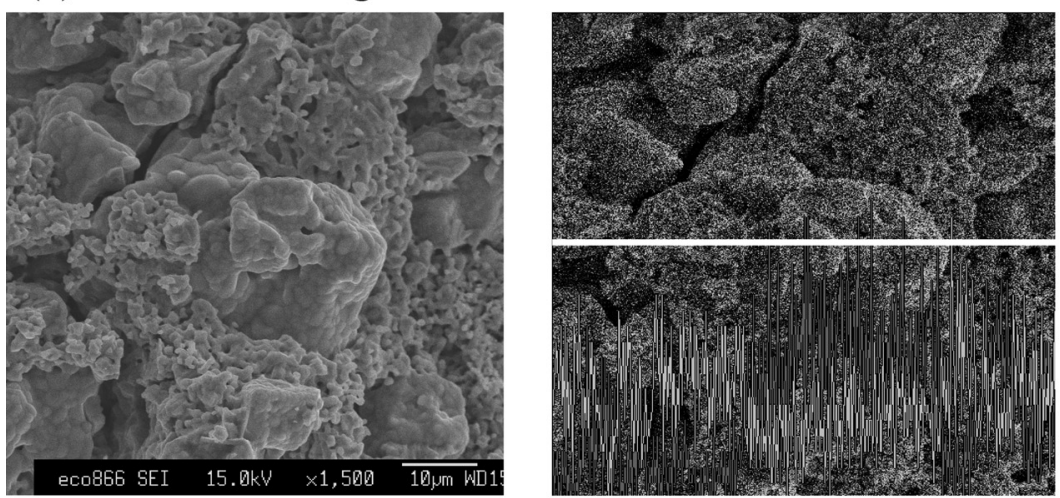

(b) $1443 \mathrm{~K}$ holding for $300 \mathrm{~s}$
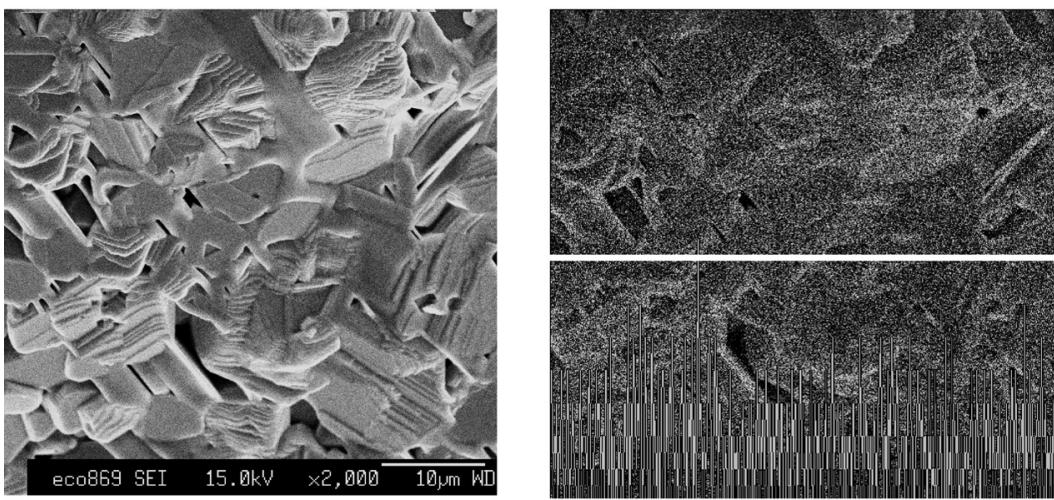

$\longrightarrow \mathrm{Ca}=\mathrm{Fe}$

Fig. 12. SEM images and EDS line analyses of $\mathrm{CaO}(10 \mu \mathrm{m})-\mathrm{FeO}$ pellet after heating.

was fully melting from their appearance observed with SEM. This is because the slight amount fine $\mathrm{CaO}$ particles are very difficult to be distinguished by SEM.

Figure 13 shows changes in intensities of $\mathrm{CaO}$ peaks in XRD pattern with the holding time for $\mathrm{CaO}$ particles of the average diameters of 75 and $10 \mu \mathrm{m}$. After heating at $1793 \mathrm{~K}$ for $120 \mathrm{~s}$, almost the same intensities of $\mathrm{CaO}$ peaks were detected for Samples 3 with the different $\mathrm{CaO}$ particle sizes. With increasing the holding time, the intensity of $\mathrm{CaO}$ peak decreased very fast for $\mathrm{CaO}$ particles of the average diameter of $10 \mu \mathrm{m}$. After $600 \mathrm{~s}$, the $\mathrm{CaO}$ peak disappeared, indicating that the additionally added $\mathrm{CaO}$ particles were completely melted down with the slag. But until holding for $1200 \mathrm{~s}$, the $\mathrm{CaO}$ peak could be detected for $\mathrm{CaO}$ particles of the average diameter of $75 \mu \mathrm{m}$. It is therefore concluded that with decreasing $\mathrm{CaO}$ particle size, the dissolution rate of $\mathrm{CaO}$ particles into molten slag of $40 \% \mathrm{CaO}-$ $40 \% \mathrm{SiO}_{2}-20 \% \mathrm{Al}_{2} \mathrm{O}_{3}$ is greatly increased.

\subsection{Melting of ( $\left.\mathrm{CaO}-\mathrm{SiO}_{2}-\mathrm{FeO}\right)-\mathrm{CaO}$ Flux}

From the ternary phase diagram of $\mathrm{CaO}-\mathrm{SiO}_{2}-\mathrm{FeO},{ }^{1)}$ Slag 2 containing $\mathrm{CaO}, \mathrm{SiO}_{2}$ and $\mathrm{FeO}$ of $40: 40: 20$ (mass\%) has the melting point of $1593 \mathrm{~K}$, which is in the region of primary crystal of $\mathrm{CaO} \cdot \mathrm{SiO}_{2}$. It is usually employed in the steelmaking process. After $10 \mathrm{mass} \% \mathrm{CaO}$ is additionally mixed with the slag, its melting point increases to $1773 \mathrm{~K}$ and it is in the region of primary crystal of $2 \mathrm{CaO} \cdot \mathrm{SiO}_{2}$. Therefore, Samples 4 of $90 \%$ Slag $2+10 \%$

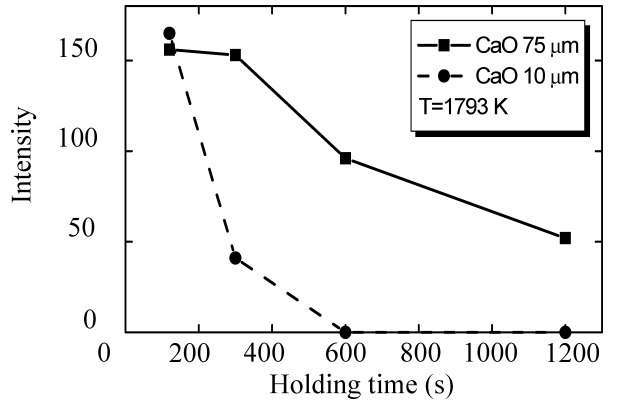

Fig. 13. Changes in intensities of $\mathrm{CaO}$ peaks in XRD patterns with time for $\left(\mathrm{CaO}-\mathrm{SiO}_{2}-\mathrm{Al}_{2} \mathrm{O}_{3}\right)-\mathrm{CaO}$ flux with different diameters of $\mathrm{CaO}$ particles.

$\mathrm{CaO}$ were heated at $1793 \mathrm{~K}$ for $120,300,600$ and $1200 \mathrm{~s}$.

Since the experimental temperature is much higher than the melting temperature of Slag 2, the Samples 4 appeared melting from the SEM observation. No difference in appearance could be detected for the different holding times.

The preliminary XRD analysis was also conducted for Slag 2, no elemental substance of $\mathrm{CaO}$ could be detected. Therefore, the $\mathrm{CaO}$ peak detected for Samples 4 after heating is originated from the additionally added $\mathrm{CaO}$ particles.

Figure 14 presents changes in intensities of $\mathrm{CaO}$ peaks in XRD patterns with holding time for $\mathrm{CaO}$ particles of the average diameter of $75 \mu \mathrm{m}$ and $10 \mu \mathrm{m}$. After heating at $1793 \mathrm{~K}$ for $120 \mathrm{~s}$, almost the same intensities of $\mathrm{CaO}$ peaks were detected for the different $\mathrm{CaO}$ particle sizes. With in- 


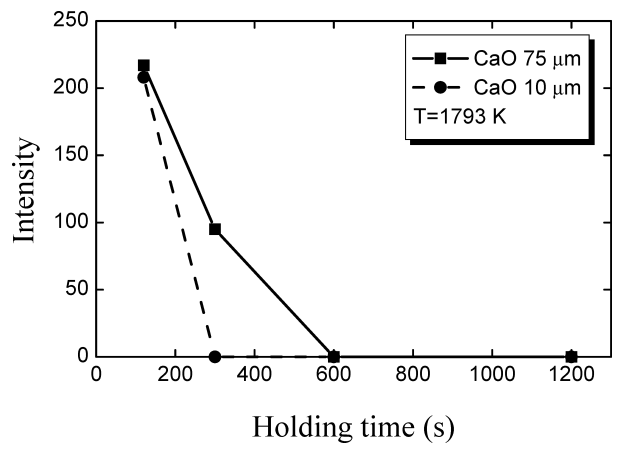

Fig. 14. Changes in intensities of $\mathrm{CaO}$ peaks in XRD patterns with time for $\left(\mathrm{CaO}-\mathrm{SiO}_{2}-\mathrm{FeO}\right)-\mathrm{CaO}$ flux with different diameters of $\mathrm{CaO}$ particles.

creasing the holding time, the $\mathrm{CaO}$ peaks decreased rapidly. After holding for $300 \mathrm{~s}$, the $\mathrm{CaO}$ peak could not be detected for $\mathrm{CaO}$ particles of the average diameter of $10 \mu \mathrm{m}$. After holding for $600 \mathrm{~s}$, the $\mathrm{CaO}$ peak disappeared for $\mathrm{CaO}$ particles of the average diameter of $75 \mu \mathrm{m}$. Again, with decreasing $\mathrm{CaO}$ particle size, the dissolution of $\mathrm{CaO}$ particles into the slag of $40 \% \mathrm{CaO}-40 \% \mathrm{SiO}_{2}-20 \% \mathrm{FeO}$ is greatly enhanced.

\section{Conclusions}

Effect of the $\mathrm{CaO}$ particle size on the melting behavior of lime-containing flux is studied by use of infrared-ray vacuum furnace in the present work. Two kinds of $\mathrm{CaO}$ particles of the average diameters of 10 and $75 \mu \mathrm{m}$ are used. Four kinds of lime-containing fluxes are employed, which are $\mathrm{CaO}-\mathrm{SiO}_{2}, \mathrm{CaO}-\mathrm{FeO}, \mathrm{CaO}-\mathrm{SiO}_{2}-\mathrm{Al}_{2} \mathrm{O}_{3}$ as ironmaking slag and $\mathrm{CaO}-\mathrm{SiO}_{2}-\mathrm{FeO}$ as steelmaking slag. The following conclusions can be drawn:

(1) For $\mathrm{CaO}-\mathrm{SiO}_{2}$ flux, after its melting, $2 \mathrm{CaO} \cdot \mathrm{SiO}_{2}$ and $3 \mathrm{CaO} \cdot \mathrm{SiO}_{2}$ are generated and the elemental substances of $\mathrm{CaO}$ and $\mathrm{SiO}_{2}$ can not be detected. The formation of $2 \mathrm{CaO} \cdot \mathrm{SiO}_{2}$ on the surface of $\mathrm{CaO}$ particles tends to hinder the melting of $\mathrm{CaO}$ particles. Relationships of reaction products, heating temperature and holding time are obtained for $\mathrm{CaO}-\mathrm{SiO}_{2}$ flux under the present experimental conditions. In terms of the flux melting, decreasing $\mathrm{CaO}$ particle size can shorten the holding time, but can not decrease the heating temperature.

(2) For $\mathrm{CaO}-\mathrm{FeO}$ flux, the relationships of reaction products, heating temperature and holding time are obtained under the present experimental conditions. With decreasing the $\mathrm{CaO}$ particle size, although the melting temperature of $\mathrm{CaO}-\mathrm{FeO}$ flux can not be decreased, the holding time can be shortened.

(3) Decreasing the $\mathrm{CaO}$ particle size can effectively promote the dissolution of $\mathrm{CaO}$ particles into both kinds of slag of $\mathrm{CaO}-\mathrm{SiO}_{2}-\mathrm{Al}_{2} \mathrm{O}_{3}$ and $\mathrm{CaO}-\mathrm{SiO}_{2}-\mathrm{FeO}$.

\section{Acknowledgement}

This study was supported in part by JFE 21 st Century Foundation, Grants-in-Aid for Scientific Research in 2006-2007.

\section{REFERENCES}

1) Hand Book of Iron and Steel (I), ed. by ISIJ, Maruzen, Tokyo, (1981), 47.

2) T. Shoji, T. Mitsuo, Y. Hatta, H. Ono, H. Mori and T. Kai: Tetsu-toHagané, 68 (1982), 609.

3) S. Ban-ya, M. Hino, R. Nagabayashi and O. Terayama: Tetsu-toHagané, 75 (1989), 66

4) S. Mukawa and Y. Mizukami: Tetsu-to-Hagané, 82 (1996), 659.

5) S. Mukawa: Tetsu-to-Hagané, 90 (2004), 408

6) I. Shimoda, T. Sato, T. Nakasuga, K. Nakashima and K. Mori: Tetsuto-Hagané, 90 (2004), 401.

7) M. Lee and P. Barr: Steel Res., 73 (2002), 123.

8) W. J. Schlitt and G. W. Healy: Am. Ceram. Soc. Bull., 50 (1971), 954.

9) H. Kimura, T. Yanagase, F. Noguchi and Y. Ueda: J. Jpn. Inst. Met., 38 (1974), 226.

10) F. Noguchi, Y. Ueda and T. Yanagase: J. Jpn. Inst. Met., 41 (1977), 883.

11) M. Matsushima, S. Yadoomaru, K. Mori and Y. Kawai: Trans. Iron Steel Inst. Jpn., 17 (1977), 442.

12) C. A. Natalie and J. W. Evans: Ironmaking Steelmaking, 6 (1979), 101.

13) T. Hamano, M. Horibe and K. Ito: ISIJ Int., 44 (2004), 263.

14) T. Hamano, S. Fukagai and F. Tsukihashi: ISIJ Int., 46 (2006), 490.

15) S. H. Amini, M. P. Brungs, S. Jahanshahi and O. Ostrovski: Metall. Mater. Trans. B, 37B (2006), 773.

16) E. M. Levin, C. R. Robbins and H. F. Mcmurdie: Phase Diagrams for Ceramists, The American Ceramic Society, Columbus, USA, (1964), 49. 